\title{
PENYUSUNAN LAPORAN KEUANGAN MASJID BERDASARKAN PSAK 45
}

\author{
Mohammad Rizka Cholid Fauzi ${ }^{1}$, Nina Dwi Setyaningsih ${ }^{2}$ \\ Universitas Islam Negeri Maulana Malik Ibrahim Malan 1,2 \\ Jalan Gajayana No. 50 Malang, 65144, Indonesia \\ e-mail: rizkacholidfauzi@gmail.com ${ }^{1}$
}

\section{Abstract}

Funds needed by the mosque are mostly obtained from public. The funds obtained can be used and responsibly according their use. More people providing fund to mosque, management must be give a report or financial statement based on financial accounting standard. The purpose of this research is to find out and do the mosque financial report based on PSAK 45, so can give a facility to give an infotmation related mosque finance. This research uses a qualitative approach with descriptive methods. The data obtained in this study came from observations, interviews and documentation The results of this study are the mosque management still has not applied PSAK 45 in the compiling of financial statements.

Keyword: Compiling, PSAK 45, Mosque

\section{Abstrak}

Dana yang dimiliki masjid sebagian besar didapatkan dari masyarakat umum. Dana yang diperoleh tersebut dapat digunakan dan dipertanggung jawabkan sesuai dengan penggunaannya. Semakin banyak masyarakat yang memberikan dana kepada masjid sudah seharusnya pengurus masjid memberikan laporan penggunaan dana atau laporan keuangan sesuai dengan standar akuntansi keuangan (SAK). Tujuan dari penelitian ini yaitu untuk mengetahui dan melakukan penyusunan laporan keuangan masjid sesuai dengan PSAK 45, sehingga dapat memberikan kemudahan dalam mendapatkan informasi yang berhubungan dengan keuangan masjid. Penelitian ini menggunakan pendekatan kualitatif dengan metode deskriptif. Data yang diperoleh pada penelitian ini berasal dari hasil observasi, wawancara dan dokumentasi Hasil dari penelitian ini adalah pengelola masjid masih belum menerapkan PSAK 45 dalam penyusunan laporan keuangannya.

Kata Kunci: Penyusunan, PSAK 45, Masjid

\section{PENDAHULUAN}

Penyusunan laporan keuangan merupakan hal yang biasa dilakukan oleh pengelola ataupun pengurus dari organisasi ketika sudah melewati atau akan memasuki akhir periode. Hal tersebut dilakukan untuk menggambarkan kondisi dan posisi keuangan organisasi pada periode tersebut. Selain itu laporan keuangan juga dapat digunakan untuk bahan pertimbangan dalam pengambilan keputusan dan kepentingan diluar organisasi itu sendiri. Dalam melakukan penyusunan laporan keuangan terdapat perbedaan antara organisasi nirlaba dengan organisasi profit orientented (laba). Perbedaan tersebut berasal dari asal dana yang diperoleh dari kedua organisasi tersebut. Pada organisasi nirlaba dana yang diperoleh dapat berasal dari sumbangan masyarakat, infaq 
maupun shodaqoh, dana yang diperoleh tersebut haruslah digunakan untuk kepentingan bersama dan tidak mementingkan suatu golongan tertentu. Sedangkan pada organisasi laba dana yang diperoleh dapat berupa dana pribadi ataupun patungan oleh dua atau lebih orang yang bekerja sama dan dana yang diperoleh tersebut selanjutnya digunakan untuk aktivitas operasi organisasi tersebut untuk mendapatkan laba sebesar - besarnya. (Bastian:2012).

Dalam melakukan penyusunan laporan keuangan pada organisasi nirlaba (masjid) terdapat standar yang mengatur tentang penyajian laporan keuangannya. Pada penelitian ini standar akuntansi keuangan untuk organisasi nirlaba yaitu menggunakan PSAK 45 revisi tahun 2017. Dimana terdapat empat komponen yang dapat disajikan dalam menyajikan laporan keuangan. Diantaranya yaitu laporan posisi keuangan, laporan aktivitas, laporan arus kas dan catatan atas laporan keuangan. (IAI:2017).

Disusunnya laporan keuangan pada organisasi nirlaba khususnya organisasi masjid, dapat memberikan dampak positif baik bagi pengurus masjid maupun lembaga atau organisasi masjid tersebut. (Rahayu:2014). Sehingga diharapkan dengan disusunnya laporan keuangan dengan PSAK 45 dapat meningkatkan kepercayaan masyarakat terhadap sistem pengelolaan yang dilakukan oleh pengurus atau ta'mir masjid akan dana yang telah diberikannya.

Adapun hasil penelitian - penelitian terdahulu yang membahas tentang keuangan masjid. Penelitian terdahulu yang dilakukan oleh Aisyah (2019), hasil penelitiannya yaitu pada Masjid Agung Lamongan masih belum menerapkan PSAK pada penyajian laporan keuangannya. Nariasih dkk (2017) hasil penelitian yang dilakukan yaitu pada Masjid XYZ masih belum menerapkan PSAK 45 maupun PSAK 109 pada laporan keuangannya. Andikawati (2014) hasil penelitian ini tersebut menunjukkan pada masjid Agung Anaz Mahfudz dan masjid Al-Huda Lumajang masih belum menerapkan PSAK 45 dalam laporan keuangannya. Sedangkan pada penelitian yang dilakukan oleh Wulandari (2015) menunjukkan bahwa pada masjid Al-Falah Surabaya telah menerapkan PSAK 45 dalam laporan keuangannya. Penelitian yang dilakukan Rahayu (2014) penelitian tersebut menunjukkan bahwa pada masjid Al-Akbar Surabaya telah menerapkan PSAk 45 dalam penyusunan laporan keuangannya.

Pada penelitian ini, penulis melakukan pengamatan untuk mengetahui proses penyajian laporan keuangan Masjid Miftahul Jannah Kabupaten Blitar dan melakukan penyusunan laporan keuangan sesuai dengan standar akuntansi keuangan PSAK 45. Tujuan dari penelitian ini yaitu menyajikan laporan keuangan Masjid Miftahul Jannah Kabupaten Blitar sesuai dengan PSAK 45 dengan harapan adanya laporan keuangan ini dapat memberikan informasi umum lainnya.

\section{KAJIAN PUSTAKA}

Laporan Keuangan

Laporan merupakan sarana yang dapat digunakan untuk menyampaikan informasi berupa laporan keuangan perusahaan kepada pihak-pihak yang membutuhkan, baik untuk pihak internal maupun pihak eksternal perusahaan yang disajikan dalam bentuk satuan mata uang. (Kieso et al, 2018). Informasi yang dihasilkan 
Mohammad Rizka Cholid Fauzi dan Nina Dwi Setyaningsih : Penyusunan Laporan Keuangan Masjid Berdasarkan PSAK 45

tersebut merupakan hasil atas olah dari berbagai sumber data yang diolah dengan menggunakan ilmu akuntansi yang sedemikian rupa sehingga dapat menghasilkan informasi kualitatif yang dapat digunakan secara umum.

Informasi yang dihasilkan tersebut dapat digunakan untuk kepentingan internal seperti digunakan sebagai pertimbangan dalam pengambilan keputusan oleh manajer dan mengetahui kondisi keuangan perusahaan. Selain itu pihak eksternal juga dapat menggunakan informasi keuangan perusahaan untuk menilai perusahaan dalam menghasilkan kas masuk untuk kepentingan para investor (Kieso et al, 2018).

\section{PSAK 45}

Pernyataan Standar Akuntansi Keuangan (PSAK) No.45 merupakan standar yang digunakan oleh entitas organisasi atau lembaga nirlaba dalam menyusun laporan keuangannya. Pengaturan khusus untuk nirlaba menggunakan PSAK No.45 yang berbeda dengan organisasi lain dikarenakan terdapat perbedaan yang terletak pada perolehan sumber dana yang didapatkan yang sebagian besar merupakan dana hasil himpunan dari publik atau masyarakat yang tidak mengharapkan adanya bentuk timbal balik ataupun imbalan dalam pemberiannya kepada organisasi tersebut.(Andikawati dkk:2014).

Dalam PSAK 45 terdapat empat laporan yang disajikan, diantaranya yaitu: Laporan Posisi Keuangan

Laporan yang berisikan daftar yang dibuat secara sistematis yang dimulai dari aset, utang atau liabilitas dan aset neto, selain itu juga terdapat informasi mengenai hubungan antara unsur-unsur yang terdapat pada periode tertentu. (Nariasih:2017).

Laporan Aktivitas

Laporan aktivitas merupakan laporan keuangan yang menyajikan informasi atas terjadinya perubahan jumlah saldo aset neto yang diakibatkan adanya transaksi transaksi yang dilakukan sebagai kegiatan operasional organisasi. (IAI:2017). Laporan aktivitas juga dapat menunjukkan pembatasan - pembatasan atas aset yang dimiliki oleh masjid yang diberikan oleh donatur.

Terdapat dua komponen penyusun dalam laporan aktivitas, yaitu pendapatan dan beban. Pendapatan dalam laporan aktivitas menjadikan penambah dari jumlah aset yang dimiliki oleh organisasi atau entitas tersebut. Pendapatan dapat diklasifikasikan berdasarkan dana yang melekat pada pendapatan tersebut (terikat atau tidak terikat). (Nariasih:2017). Beban juga akan menjadi pengurang dalam laporan aktivitas, dikarenakan sifat beban merupakan pengurang dari setiap laporan. Sama halnya dengan pendapatan, beban juga terdapat pembatasan berdasarkan ada tidaknya pembatasan yang diberikan oleh donatur.

Laporan Arus Kas

Laporan arus kas menyajikan informasi mengenai jumlah penerimaan dan pengeluaran kas yang dilakukan selama satu periode tertentu. (IAI:2017). Menurut Rudianto (2018) dalam melakukan penyusunan laporan arus kas terdapat tiga aktivitas utama yaitu aktivitas operasi, aktivitas investasi dan aktivitas pendanaan. Aktivitas operasi merupakan kegiatan - kegiatan yang rutin dilakukan sebagai penunjang aktivitas utama pada organisasi tersebut. Selain itu juga terdapat aktivitas investasi yang berisi 
pengadaan peralatan yang dapat digunakan sebagai penunjang atau fasilitas yang diberikan untuk dapat digunakan secara bersama. Aktivitas yang ketiga yaitu kegiatan pendanaan, dimana aktivitas pendanaan ini dapat berupa peminjaman dana ataupun pemerolehan atas suatu aset. Aktivitas pendanaan ini bertujuan untuk dapat memperkitakan klaim atas arus kas yang akan datang.

Catatan Atas Laporan Keuangan

Catatan atas laporan keuangan merupakan bagian pelengkap dari laporan keuangan yang memuat berbagai informasi yang berhubungan dengan penyajian laporan keuangan diatas. Pada dasarnya catatan atas laporan keuangan memuat informasi yang sifatnya kualitatif, akan tetapi dapat juga berbentuk kuantitatif dengan tujuan untuk menambah informasi yang terdapat pada laporan keuangan tersebut.

\section{METODE}

Penelitian ini menggunakan pendekatan kualitiatif dengan metode deskriptif. Penelitian dilakukan pada Masjid Agung Miftahul Jannah yang berada di DesaBeru Kecamatan Wlingi Kabupaten Blitar. Objek penelitian yang digunakan dalam penelitian ini yaitu berupa laporan keuangan maupun catatan - catatan pendukung lainnya. Dalam melakukan penelitian ini terdapat dua sumber data yang digunakan, yaitu data primer dan data sekunder yang didapatkan dari pengurus atau ta'mir Masjid Agung Miftahul Jannah. Pengumpulan data dilakukan dengan tiga teknik pengumpulan, yaitu dengan melakukan observasi dengan mengamati kegiatan yang berlangsung setiap harinya, melakukan wawancara langsung kepada ketua ta'mir dan bendahara masjid, dokumentasi dilakukan dengan melakukan pengumpulan berupa dokumen - dokumen pendukung penelitian seperti laporan keuangan dan buku pendukung lainnya. Analisis data dilakukan menggunakan teknik analisis interaktif yang digunakan untuk menentukan kesimpulan akhir.

\section{HASIL DAN PEMBAHASAN}

\section{Gambaran Umum}

Masjid merupakan salah satu organisasi masjid yang bertujuan sebagai penyedia tempat untuk melakukan ibadah bagi umat Islam. Selain itu masjid juga digunakan sebagai tempat untuk penyelenggaraan kegiatan - kegiatan yang berhubungan dengan agama maupun kegiatan sosial lainnya. Dimana masjid tentunya memliki berbagai fasilitas - fasilitas penunjang yang dapat digunakan untuk melaksanakan kegiatan kegiatan tersebut.

Secara umum masjid bergerak tidak untuk mencari keuntungan, melainkan untuk melayani keperluan masyarakat umum dalam hal peribadatan. Organisasi masjid berbeda dengan organisasi - organisasi profit lainnya. Dimana masjid dalam mencukupi kebutuhan operasional dan pengadaan fasilitas mendapatkan dana yang didapatkan dari berbagai sumber. Dimana masjid mendapatkan dana dari hasil infaq, sumbangan, shodaqoh dan berbagai lini bisnis masjid seperti warung atau kios, parkir, penyewaan gedung dan lainnya. Sama halnya dengan yang dilakukan oleh pengurus Masjid Agung 
Mohammad Rizka Cholid Fauzi dan Nina Dwi Setyaningsih : Penyusunan Laporan Keuangan Masjid Berdasarkan PSAK 45

Miftahul Jannah dalam melakukan pengumpulan dananya. Yang selanjutnya hasil pendapatan tersebut dapat digunakan untuk kepentingan masjid.

\section{Laporan Keuangan Masjid Agung Miftahul Jannah}

Laporan keuangan Masjid Agung Miftahul Jannah dilakukan pencatatan setiap akhir bulan. Pencatatan tersebut dilakukan oleh bendahara umum masjid yang dibantu oleh seseorang yang diberikan tugas untuk mencatat pengeluaran harian dan mencatat pemasukan masjid yang didapatkan dari kotak amal setiap hari Jumat. Selain itu ia juga ditugaskan untuk melaporkan kepada bendahara umum atas pemasukan dan pengeluaran yang diberikan setiap akhir bulannya.

Pencatatan yang dilakukan tersebut dilakukan dengan ditulis dalam sebuah buku yang disebut dengan buku kas. Pencatatan pada buku kas tersebut dilakukan atas bukti bukti transaksi yang menjadikan dokumen pendukung dalam pembuatan laporan keuangan. Dokumen tersebut berfungsi sebagai penguat atas pengeluaran kas atau dana yang telah dilakukan, sehingga memiliki cukup bukti atas terjadinya suatu transaksi. Selain beban - beban juga terdapat pendapatan - pendapatan yang dicatat dalam laporan keuangan tersebut. Pendapatan tersebut dipisahkan berdasarkan sumbernya, yang dibagi menjadi tiga bagian yaitu kotak amal jumat, infaq dan shodaqoh.

Pengitungan dilakukan oleh beberapa pengurus masjid dan seseorang yang diberikan amanah atau tugas oleh bendahara untuk mencatat dan melaporkannya. Penghitungan dilakukan sebanyak satu minggu sekali yaitu setiap selesai sholat jumat. Selanjutnya dana tersebut akan dimasukkan kedalam brankas masjid dan dicatat untuk dilaporkan kepada bendahara umum setiap minggunya.

\section{Penyusunan Laporan Keuangan Berdasarkan PSAK 45}

Penyusunan laporan keuangan ini berdasarkan pada PSAK 45 tahun 2017 tentang organisasi nirlaba, adapun komponen laporan keuangan berdasarkan PSAk 45 terdapat empat komponen yaitu

Laporan Posisi Keuangan

Pengelompokan aset pada Masjid Miftahul Jannnah terbagi atas aset lancar dan aset tidak lancar. Aset lancar dibagi atas aset yang memiliki perputaran yang dianggap lebih cepat (likuid), sedangkan pada aset tidak lancar merupakan aset yang dianggap memiliki perputaran lebih lama daripada aset lancar seperti bangunan, tanah dan peralatan.

Tidak terdapat nilai hutang pada laporan keuangan Masjid Miftahul Jannah, hal tersebut merupakan akibat dari penerapan pembayaran tunai pada setiap transaksi yang dilakukan. Aset neto merupakan pengelompokan atas aset yang dimiliki oleh masjid berdasarkan pada ketentuan atau kebijakan dari pemberi dana. Pada aset neto pada Masjid Miftahul Jannah hanya terdiri dari aset neto tidak terikat, yang berarti bahwa aset yang berasal dari publik tidak terdapat keterikatan atau batasan dalam penggunaannya. Sehingga aset yang dimiliki tersebut dapat digunakan sesuai dengan kebutuhan yang diperlukan oleh pengurus untuk kepentingan bersama. Berikut ini merupakan laporan posisi keuangan Masjid Miftahul Jannah berdasarkan PSAK 45. 
Mohammad Rizka Cholid Fauzi dan Nina Dwi Setyaningsih : Penyusunan Laporan Keuangan Masjid Berdasarkan PSAK 45

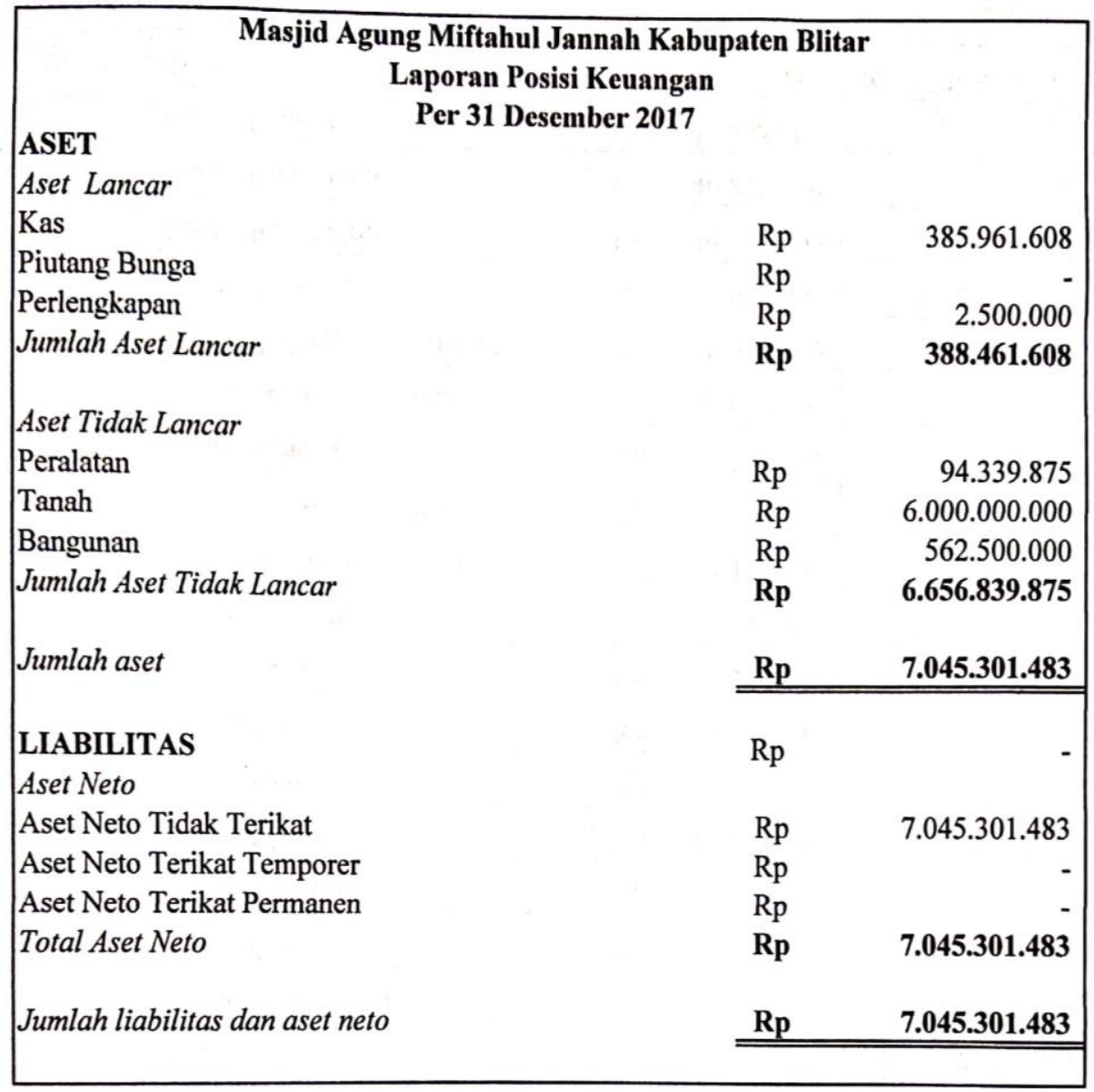

Gambar 1. Laporan Posisi keuangan Masjid Agung Miftahul Jannah Sumber : Penulis

Laporan Aktivitas

Pada Masjid Miftahul Jannah masih belum disajikan laporan aktivitas didalam laporan keuangannya. Pada laporan tersebut selain dapat menunjukkan jumlah aset neto yang dimiliki dan juga kegiatan transaksi yang dilakukan, juga dapat memberikan informasi tentang aset - aset yang diberikan pembatasan oleh donatur. 
Mohammad Rizka Cholid Fauzi dan Nina Dwi Setyaningsih : Penyusunan Laporan Keuangan Masjid Berdasarkan PSAK 45

Berikut merupakan penyajian laporan aktivitas berdasarkan PSAK 45 pada Masjid Miftahul Jannah:

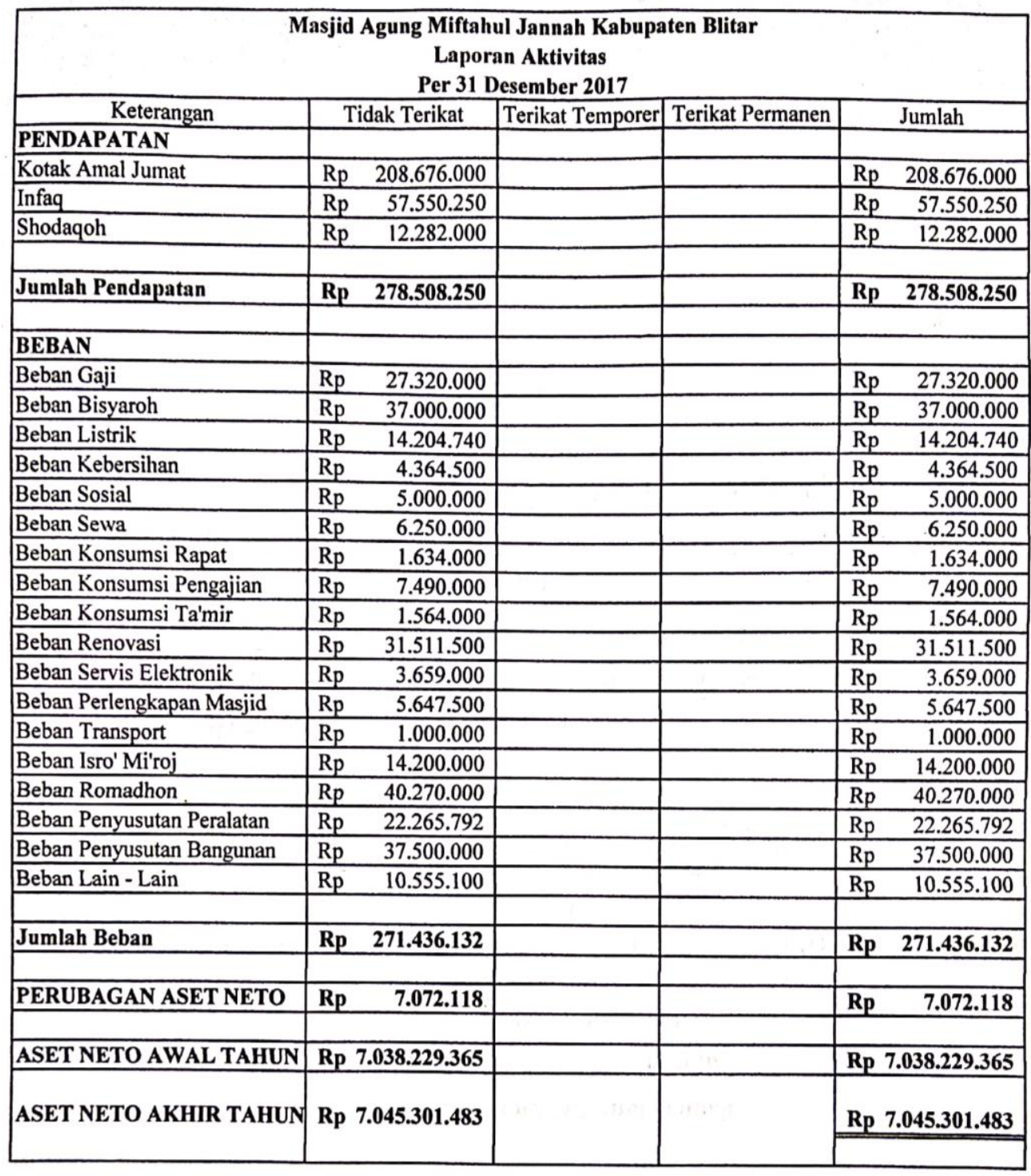

\section{Gambar 2. Laporan Aktivitas keuangan Masjid Agung Miftahul Jannah}

Sumber : Penulis (2018)

Laporan Arus Kas

Adapun arus kas pada Masjid Agung Miftahul Jannah sesuai PSAK 45 sebagai berikut. 
Mohammad Rizka Cholid Fauzi dan Nina Dwi Setyaningsih : Penyusunan Laporan Keuangan Masjid Berdasarkan PSAK 45

\begin{tabular}{|c|c|c|}
\hline \multicolumn{3}{|c|}{$\begin{array}{c}\text { Masjid Agung Miftahul Jannah Kabupaten Blitar } \\
\text { Laporan Arus Kas } \\
\text { Per } 31 \text { Desember } 2017\end{array}$} \\
\hline $\begin{array}{l}\text { AKTIVITAS OPERASI } \\
\text { Pendapatan : }\end{array}$ & & \\
\hline Kas dari kotak amal jumat & Rp & 208.676.000 \\
\hline Kas dari infaq & $R_{p}$ & 57.550 .250 \\
\hline Kas dari shodaqoh & $\mathrm{Rp}$ & 12.282 .000 \\
\hline Total Pendapatan & $\mathrm{Rp}$ & 278.508 .250 \\
\hline Pengeluaran : & & \\
\hline Perlengkapan & Rp & 1.000 .000 \\
\hline Beban Gaji & $\mathbf{R p}$ & 27.320 .000 \\
\hline Beban Bisyaroh & $R_{p}$ & 37.000 .000 \\
\hline Beban Listrik & $\mathrm{Rp}$ & 14.204 .740 \\
\hline Beban Kebersihan & $\mathrm{Rp}$ & 4.364.500 \\
\hline Beban Sosial & $\mathbf{R p}$ & 5.000 .000 \\
\hline Beban Sewa & $\mathbf{R}_{\mathbf{p}}$ & 6.250 .000 \\
\hline Beban Konsumsi Rapat & $\mathbf{R p}$ & 1.634 .000 \\
\hline Beban Konsumsi Pengajian & $\mathbf{R p}$ & 7.490 .000 \\
\hline Beban Konsumsi Ta'mir & $\mathbf{R p}$ & 1.564 .000 \\
\hline Beban Renovasi & $R_{p}$ & 31.511 .500 \\
\hline Beban Servis Elektronik & Rp & 3.659 .000 \\
\hline Beban Perlengkapan Masjid & $\mathbf{R p}$ & 5.647 .500 \\
\hline Beban Transport & $\mathbf{R p}_{\mathbf{p}}$ & 1.000 .000 \\
\hline Beban Isro' Mi'roj & Rp & 14.200 .000 \\
\hline Beban Romadhon & $\mathbf{R p}$ & 40.270 .000 \\
\hline Beban Lain - Lain & $\mathrm{Rp}_{\mathrm{p}}$ & 10.555 .100 \\
\hline Total Pengeluaran & $\mathrm{Rp}$ & 212.670 .340 \\
\hline $\begin{array}{l}\text { Kas neto yang diterima (digunakan untuk aktivitas } \\
\text { operasi }\end{array}$ & $\mathbf{R p}$ & 65.837 .910 \\
\hline $\begin{array}{l}\text { AKTIVITAS INVESTASI } \\
\text { Pembelian peralatan }\end{array}$ & Rp & 82.201 .500 \\
\hline $\begin{array}{l}\text { Kas neto yang diterima (digunakan untuk aktivitas } \\
\text { investasi }\end{array}$ & $\mathbf{R p}$ & 82.201.500 \\
\hline AKTIVITAS PENDANAAN & $\mathbf{R p}$ & - \\
\hline $\begin{array}{l}\text { KENAIKAN (PENURUNAN) NETO DALAM KAS } \\
\text { DAN SETARA KAS }\end{array}$ & $\mathbf{R p}$ & (16.363.590) \\
\hline KAS DAN SETARA KAS AWAL TAHUN & $\mathbf{R} \mathbf{p}$ & 402.325.198 \\
\hline KAS DAN SETARA KAS AKHIR TAHUN & $\mathbf{R p}$ & 385.961.608 \\
\hline
\end{tabular}

Gambar 3. Laporan Arus Kas Masjid Agung Miftahul Jannah Sumber : Penulis (2018)

Catatan Atas Laporan Keuangan

Penyajian catatan atas laporan keuangan pada Masjid Agung Miftahul Jannah ini sudah sesuai dengan yang dimaksud pada PSAk 45.

\section{KESIMPULAN}

Berdasarkan pada hasil penelitian yang dilakukan pada Masjid Agung Miftahul Jannah, diketahui bahwa laporan keuangan yang disusun masih belum sesuai dengan yang diatur dalam PSAK 45. Penyajian laporan keuangan berbasis kas, dimana laporan keuangan yang disusun oleh pengurus masjid masih pada laporan keuangan sederhana yang hanya menyajikan informasi kas masuk dan kas keluar.

Saran yang dapat diberikan oleh penulis yaitu penyajian untuk laporan keuangan pada periode selanjutnya dapat menggunakan laporan keuangan sesuai dengan PSAK 45. Selain itu saran untuk peneliti selanjutnya yaitu untuk melakukan penelitian dengan 
Mohammad Rizka Cholid Fauzi dan Nina Dwi Setyaningsih : Penyusunan Laporan Keuangan Masjid Berdasarkan PSAK 45

waktu yang lebih panjang untuk dapat memberikan informasi yang lebih lengkap mengenai pengungkapan aset yang dimiliki oleh masjid.

\section{DAFTAR PUSTAKA}

Aisyah, Nur. 2019. Akuntabilitas Pada Pengelolaan Keuangan Masjid Agung Lamongan Mneurut PSAK 45 Tentang Pelaporan Keuangan Organisasi Nirlaba. Diperoleh tanggal 1 April 2019 dari digilib.uinsby.ac.id

Andarsari, Pipit Rosita. 2016. Laporan Keuangan Organisasi Nirlaba (Lembaga Masjid). Jurnal Ekonomi Universitas Kadiri Vol. 1 No.2.

Andikawati, Desi., \& Winarno, Agus Wahyu. 2014. Laporan Keuangan Lembaga Masjid (Studi Kasus Pada Lembaga Masjid Agung Anaz Mahfudz Dan Masjid Al-Huda Lumajang). Artikel Ilmiah Mahasiswa 2014.

Bastian, Indra. 2012. Akuntansi Sektor Publik Suatu Pengantar. Edisi Ketiga Jakarta : Erlangga

Dewan Standar Akuntansi Keuangan. 2017. Standar Akuntansi Keuangan Jakarta : IAIEdisi IFRS. Jakarta:Salemba Empat

Kieso, Weygandt, Warfield (2018). Akuntansi Keuangan Menengah Volume 1

Nariasih, Dewi Yibta., Kurrohman, Taufik., \& Andriana. 2017. Laporan Keuangan Masjid Berdasarkan Kombinasi PSAK Nomor 45 dan PSAK Nomor 109 (Studi Kasus Pada Masdji XYV). E-Journal Ekonomi Bisnis dan Akuntansi Vol.4 No.1.

Nariasih, Dewi Yibta., Kurrohman, Taufik., \& Andriana. 2017. Laporan Keuangan Masjid Berdasarkan Kombinasi PSAK Nomor 45 dan PSAK Nomor 109 (Studi Kasus Pada Masdji XYV). E-Journal Ekonomi Bisnis dan Akuntansi Vol.4 No.1.

Rahayu, Ruci Arizanda. 2014. Tranparansi dan Akuntabilitas Pelaporan Keuangan Masjid Agung Al-Akbar Surabaya. Jurnal Reviu Akuntansi dan Keuangan Vol.4 No.2.

Wulandari, Fresisca. 2015. Penerapan PSAK 45 Dalam Mengkomunikasikan Aktivitas Pelayanan Masjid Al-Falah Surabaya Terhadap Publik. Jurnal Ilmiah Mahasiswa Universitas Surabaya Vol.4 No. 